\title{
PERANAN VALUE FOR MONEY UNTUK MENGUKUR KINERJA PEMERINTAHAN KABUPATEN BULELENG
}

\author{
PUTU ADI ERAWAN, MD SATRIA WIRA ADI SANTOSA, DEWA KOMANG BENY \\ BUDIARTHA, I PUTU TEDY ARYA WAHYUDI \\ Jurusan Akuntansi, Universitas Pendidikan Ganesha, Singaraja, Bali, Indonesia
}

\begin{abstract}
Abstrak
Penelitian ini bertujuan untuk mengetahui peran value for money dalam mengukur kinerja Pemerintahan Kabupaten Buleleng. Value for Money merupakan konsep pengelolaan organisasi sektor publik yang berdasarkan pada tiga elemen utama, yaitu ekonomi, efisiensi, dan efektivitas. Penelitian ini dilakukan dengan metode kualitatif yang mentitikberatkan pada deskripsi serta interpretasi perilaku manusia. Data diperoleh melalui wawancara mendalam, observasi dan studi dokumen. Data ini selanjutnya diolah melalui tiga tahapan, yaitu: 1) reduksi data, 2) penyajian data, 3) analisis data dan penarik kesimpulan berdasarkan teori yang telah ditentukan. Hasil penelitian mengungkap bahwa dari hasil observasi yang dilakukan memaparkan mengenai ketimpangan dan penyalahgunaan konsep value for money yang kini memengaruhi kinerja Pemerintahan kabupaten Buleleng.
\end{abstract}

Kata Kunci : Value For Money, Mengukur, Kinerja, Pemerintahan

\begin{abstract}
This study aims to study the role of value for money in measuring the performance of the Government of the Regency of Buleleng. This research was conducted with a qualitative method that emphasizes human description and interpretation. Data obtained through interviews, observation and document study. This data is then processed through three stages, namely: 1) data reduction, 2) data presentation, 3) data analysis and drawing conclusions based on predetermined theories. The results of the study reveal the results of observations made about inequality and discuss the concept of value for money which now affects the performance of the Government of the district of Buleleng.
\end{abstract}

\section{Keywords: Value For Money, Measuring, Performance, Governance}

\section{Pendahuluan}

Organisasi sektor publik saat ini tengah menghadapi tekanan untuk lebih efisien, memperhitungkan biaya ekonomi dan biaya sosial, serta dampak negatif atas aktivitas yang dilakukan. Berbagai tuntutan tersebut menyebabkan akuntansi dapat dengan cepat diterima dan diakui sebagai ilmu yang dibutuhkan untuk mengelola urusan-urusan publik. Akuntansi sektor publik pada awalnya merupakan aktivitas yang terspesialisasi dari suatu profesi yang relatif kecil. Namun demikian, saat ini akuntansi sektor publik sedang mengalami proses untuk menjadi disiplin ilmu yang lebih dibutuhkan dan substansial keberadaannya. Pemerintahan Kabupaten Buleleng merupakan lembaga pemerintahan di Buleleng yang bertanggungjawab untuk meningkatkan kesejahteraan masyarakat di Buleleng dalam bidang ekonomi, menjunjung tinggi keinginan masyarakat, membantu pemerintah daerah melaksanakan pembangunan berkelanjutan dan berkeadilan sosial, menjalankan aspekaspek fungsional dari lembaga nonkeuangan secara efisien dan efektif sehingga bisa terwujud good governance dengan sebenarnya, (Mahsun, 2012: 20).

Good Governance akan tercapai jika lembaga pengawas dan pemeriksa berfungsi secara baik. Apabila lembaga pengawas dan pemeriksa telah tertata dengan baik, maka 
yang perlu dilakukan adalah memperbaiki teknik pengawasan dan pemeriksaan. Salah satunya adalah dengan memperkuat pelaksanaan audit kinerja (value for money atau performance audit). Sebagaimana diatur dalam Standar Audit Pemerintahan (SAP) tahun 1995, value for money audit atau audit kinerja adalah pengauditan yang dilakukan untuk memeriksa tingkat ekonomi, efisien, dan efektivitas pelaksanaan suatu program atau kegiatan dan unit kerja tertentu. Tujuan memperkuat pelaksanaan value for money tersebut adalah dalam rangka meningkatkan akuntabilitas sektor publik. Hal tersebut penting untuk mendukung pelaksanaan otonomi daerah dan pembangunan ekonomi daerah dan lembagalembaga pemerintahan daerah dan lembaga keuangan lain yang ada di daerah harus memberikan pertanggungjawaban publik kepada masyarakat. Indikasi keberhasilan otonomi daerah dan desentralisasi adalah terjadinya peningkatan perekonomian, pembangunanan dan kesejahteraan masyarakat yang semakin baik, perekonomian yang semakin maju, adanya kontribusi terhadap pemerintah daerah dalam upaya pembangunan di tingkat daerah, serta adanya hubungan yang serasi antara daerah dan kabupaten di Bali. Keadaan tersebut hanya akan tercapai apabila lembaga keuangan ini dikelola dengan memperhatikan value for money. Value for money Dalam konteks otonomi daerah, merupakan jembatan untuk menghantarkan pemerintah daerah mencapai good governance. Value for money tersebut harus dioperasionalkan dalam pengelolaan keuangan daerah dan anggaran daerah. Untuk mendukung dilakukannya pengelolaan dana publik yang mendasarkan konsep value for money, maka diperlukan sistem pengelolaan keuangan daerah dan anggaran daerah yang baik. Hal tersebut dapat tercapai apabila pemerintah daerah beserta lembaga keuangannya memiliki sistem akuntansi yang baik, (Mardiamo, 2002: 29).

Tujuan utama value for money adalah menjamin dilakukannya pertanggungjawaban publik oleh lembaga-lemabaga keuangan kepada masyarakat, yang sering disebut dengan akuntabilitas publik. Akuntabilitas dapat diartikan sebagai bentuk kewajiban mempertanggungjawabkan keberhasilan atau kegagalan pelaksanaan misi lembaga dalam mencapai tujuan dan sasaran yang telah ditetapkan sebelumnya, melalui suatu bentuk pertanggungjawaban yang dilaksanakan secara periodik. Tuntutan dilaksanakannya akuntabilitas publik mengharuskan lembaga pemerintahan kabupaten Buleleng untuk memperbaiki sistem pencatatan dan pelaporan. Pemerintahan Kabupaten Buleleng dituntut untuk tidak sekedar melakukan vertical reporting, yaitu pelaporan kepada pemerintah atasan (Pemprov Bali), akan tetapi juga melakukan horizontal reporting, yaitu pelaporan kinerja pemerintahan kabupaten kepada lembaga pemerintahan kabupaten lainnya dan masyarakat luas sebagai bentuk horizontal accountability. Salah satu tujuan reformasi pengelolaan keuangan kabupaten adalah mengubah pola pertanggung jawaban horizontal. Dikeluarkannya UU No 22 dan 25 tahun 1999 telah melahirkan paradigma baru dalam pengelolaan keuangan kabupaten dan anggaran daerah. Dalam pengelolaan keuangan kabupaten, paradigma baru tersebut berupa tuntutan dilakukannya pengelolaan keuangan kabupaten yang berorientasi pada kepentingan publik. Untuk itu pemerintahan kabupaten buleleng dituntut untuk dapat membuat laporan keuangan dan menyampaikan informasi keuangan tersebut secara transparan kepada publik. Laporan keuangan tersebut hendaknya mudah diperoleh oleh masyarakat dengan biaya murah, (Mardiamo, 2002: 32)

Akuntabilitas berhubungan terutama dengan mekanisme supervisi pelaporan, dan pertanggungjawaban kepada otoritas yang lebih tinggi dalam sebuah rantai komando formal. Pada era desentralisasi dan otonomi daerah, para manajer publik diharapkan bisa melakukan transformasi dari sebuah peran ketaatan pasif menjadi seorang yang berpartisipasi aktif dalam penyusunan standar akuntabilitas yang sesuai dengan keinginan dan harapan publik. Oleh karena itu, makna akuntabilitas menjadi lebih luas dari sekedar proses formal dan saluran untuk pelaporan kepada otoritas yang lebih tinggi. Akuntabilitas harus merujuk kepada sebuah spektrum yang luas dengan standar kinerja yang bertumpu pada harapan publik sehingga dapat digunakan untuk menilai kinerja, responsivitas, dan juga moralitas dari para pengemban amanah publik. Konsepsi akuntabilitas dalam arti luas ini menyadarkan kita bahwa pejabat lembaga keuangan tidak hanya bertanggung jawab kepada otoritas yang lebih tinggi dalam rantai komando institusional, tetapi juga bertanggungjawab kepada masyarakat umum, lembaga pemerintahaan lainyan, lembaga 
swadaya masyarakat, media masa, dan banyak stakeholder lain. Jadi, penerapan akuntabilitas ini, disamping berhubungan dengan penggunaan kebijakan administratif yang sehat dan legal, juga harus bisa meningkatkan kepercayaan masyarakat atas bentuk akuntabilitas formal yang ditetapkan, (Mahsun, 2012: 170).

Berdasarkan latar belakang permasalahan diatas, maka adapaun rumusan masalah yang dirumuskan yaitu bagimana peran value for money dalam mengukur kinerja Pemerintahan Kabupaten Buleleng.

\section{Telaah Litelatur Value For Money}

Value for Money Sebelum membahas mengenai Value for Money, terlebih dahulu akan dibahas mengenai kinerja. Kinerja adalah gambaran pencapaian pelaksanaan suatu kegiatan dalam mewujudkan sasaran, tujuan, misi, dan visi organisasi (Indra Bastian, 2006: 274). Menurut Moh Mahsun (2006) kinerja (performance) adalah gambaran mengenai tingkat pencapaian pelaksanaan suatu kegiatan/program/kebijakan dalam mewujudkan sasaran, tujuan, misi, dan visi lembaga yang tertuang dalam strategik planning suatu lembaga. Istilah kinerja sering digunakan untuk menyebut prestasi atau tingkat keberhasilan individu maupun kelompok individu. Kinerja bisa diketahui hanya jika individu atau kelompok individu tersebut mempunyai kriteria keberhasilan yang telah ditetapkan. Kriteria keberhasilan ini berupa tujuan-tujuan yang hendak dicapai. Tanpa ada tujuan atau target, kinerja seseorang atau organisasi tidak mungkin dapat diketahui karena tidak ada tolok ukurnya. Dari beberapa definisi tersebut dapat ditarik kesimpulan, kinerja merupakan suatu kondisi yang

harus diketahui kepada pihak tertentu untuk mengetahui tingkat pencapaian hasil suatu instansi atau organisasi dihubungkan dengan visi yang diemban oleh suatu organisasi.

Menurut Robertson (2002) dalam Moh. Mahsun (2006), pengukuran kinerja (performance measurement) adalah suatu proses penilaian kemajuan pekerjaan terhadap tujuan dan sasaran yang telah ditentukan sebelumnya, termasuk informasi atas: efisiensi penggunaan sumber daya dalam menghasilkan barang dan jasa; kualitas barang dan jasa (seberapa baik barang dan jasa diserahkan kepada pelanggan dan sampai seberapa jauh pelanggan terpuaskan); hasil kegiatan dibandingkan dengan maksud yang diinginkan; dan efektivitas tindakan dalam mencapai tujuan. Dapat disimpulkan bahwa pengukuran kinerja merupakan suatu metode atau alat yang digunakan untuk mencatat dan menilai pencapaian pelaksanaan kegiatan berdasarkan tujuan, sasaran, dan strategi sehingga dapat diketahui kemajuan organisasi atau lembaga serta meningkatkan kualitas pengambilan keputusan dan akuntabilitas.

Value for Money adalah suatu konsep pengukuran kinerja sektor publik yang memiliki tiga elemen utama: ekonomi, efisiensi,

dan efektivitas, dalam memanfaatkan sumber daya yang tersedia, di mana pengertian dari masing-masing elemen tersebut adalah:

1. Ekonomi, Ekonomi adalah pemerolehan sumber daya (input) tertentu pada harga yang terendah. Ekonomi merupakan perbandingan input dengan input value yang dinyatakan dalam satuan moneter. Ekonomi terkait dengan sejauh mana organisasi sektor publik dapat meminimalisir input resources dengan menghindari pengeluaran yang boros dan tidak produktif (Mardiasmo, 2009: 4). Indikator ekonomi merupakan indikator tentang input. Pertanyaan yang diajukan adalah "apakah organisasi telah mengeluarkan biaya secara ekonomis?" (Indra Bastian, 2006: 78).

2. Efisiensi, Efisiensi adalah hubungan antara input dan output di mana barang dan jasa yang dibeli oleh organisasi digunakan untuk mencapai output tertentu (Indra Bastian, 2006: 280). Efisiensi merupakan perbandingan output/input yang dikaitkan dengan standar kinerja atau target yang telah ditetapkan (Mardiasmo, 2009: 4).

3. Efektivitas, Efektivitas adalah hubungan antara output dan tujuan, di mana efektivitas diukur berdasarkan seberapa jauh tingkat output, kebijakan, dan prosedur organisasi mencapai tujuan yang telah ditetapkan (Indra Bastian, 2006: 280). Jika suatu organisasi berhasil mencapai tujuannya, maka organisasi tersebut dikatakan telah 
berjalan efektif. Efektivitas hanya melihat apakah suatu program telah mencapai tujuan yang telah ditetapkan sebelumnya (Mardiasmo, 2009: 134). Tuntutan masyarakat dalam Value for Money adalah ekonomis (hemat) dalam pengadaan dan alokasi sumber daya, efisien dalam arti bahwa penggunaan/pengorbanannya miminimalkan dan hasilnya dimaksimalkan, serta efektif (berhasil guna) dalam arti pencapaian tujuan dan sasaran. Peranan indikator kinerja pada Value for Money adalah untuk menyediakan informasi sebagai pertimbangan untuk pembuatan keputusan (Mardiasmo, 2009: 130).

Penerapan konsep Value for Money dalam pengukuran kinerja pada organisasi sektor publik tentunya memberikan manfaat bagi organisasi itu sendiri maupun masyarakat. Manfaat yang dikehendaki dalam pelaksanaan Value for Money pada organisasi sektor public yaitu: ekonomis (hemat cermat) dalam pengadaan dan alokasi sumber daya, efisien (berdaya guna) dalam penggunaan sumber daya, dan efektif (berhasil guna) dalam mencapai tujuan dan sasaran (Mardiasmo 2009: 130)

\section{Good Corporate Governance}

Organization of Economic Cooperation and Development (OECD) mendefinisikan Corporate Governance sebagai berikut: Corporate governance is the system by which business corporations are directed and controlled. The Corporate Governance structure specifies the distribution of the right and responsibilities among different participants in the corporation, such as the board, managers, shareholders, and other stakeholders, and spells out the rules and procedures for making decisions on corporate affairs. By doing this, it also provides this structure through which the company objectives are set, and the means of attaining those objectives and monitoring performance. OECD melihat Corporate Governance sebagai suatu sistem yang mana sebuah perusahaan atau entitas bisnis diarahkan dan diawasi. Sejalan dengan itu, maka struktur dari Corporate Governance menjelaskan distribusi hak-hak dan tanggungjawab dari masing-masing pihak yang terlibat dalam sebuah bisnis, yaitu antara lain Dewan Komisaris dan Direksi, Manajer, Pemegang saham, serta pihakpihak lain yang terkait sebagai stakeholders. Selanjutnya, struktur dari Corporate Governance juga menjelaskan bagaimana aturan dan prosedur dalam pengambilan dan pemutusan kebijakan sehingga dengan melakukan itu semua maka tujuan perusahaan dan pemantauan kinerjanya dapat dipertangungjawabkan dan dilakukan dengan baik. Sedangkan good corporate governance (GCG) merupakan praktik terbaik yang biasa dilakukan oleh suatu perusahaan yang berhasil yang mengacu pada bauran antara alat, mekanisme, dan struktur yang menyediakan kontrol dan akuntabilitas yang dapat meningkatkan kinerja perusahaan (Tim BPKP, 2003). Praktik terbaik ini mencakup praktik bisnis, aturan main, struktur proses, dan prinsip yang dimiliki. Perusahaan dengan praktik CG yang baik akan dapat meningkatkan nilai perusahaan bagi pemegang saham karena visi, misi dan strategi perusahaan dinyatakan dengan jelas, nilai-nilai perusahaan serta kode etik disusun untuk memastikan adanya kepatuhan seluruh jajaran perusahaan, terdapat kebijakan untuk menghindari benturan kepentingan dan transaksi dengan pihak ketiga yang tidak tepat, risiko perusahaan dikelola dengan baik dan terdapat sistem pengendalian dan monitoring yang baik (Price Waterhouse Coopers, 2000).

Terdapat enam prinsip corporate governance dalam Prinsip-prinsip OECD 2004. Prinsip - prinsip ini melandasi beberapa riset tentang pengukuran tingkat penerapan corporate governance pada perusahaan.

\section{Metode Penelitian}

Penelitian yang digunakan dalam riset ini adalah dengan menggunakan metode penelitian kualitatif. Pendekatan kualitatif merupakan pendekatan penelitian yang berlandaskan fenomenologi dan paradigma konstruktivisme dalam mengembangkan ilmu pengetahuan (Moleong, 2010:10-13 dalam Ikbar, 2012:146). Sejalan dengan itu, maka sasaran penelitian ini bukanlah pada pengukuran (kuantitas), melainkan pada pemahaman terhadap fenomena sosial dari perspektif para partisipan atau menurut perspektif emik. Penelitian ini bertujuan untuk memperoleh informasi-informasi mengenai keadaan saat ini, dan melihat kaitan antara variabel-variabel yang ada, atau dengan kata lain penelitian ini 
mendeskripsikan apa adanya sesuai dengan variabel-variabel yang diteliti. Penelitian semacam ini sering digunakan guna mengambil kebijakan atau keputusan untuk melakukan atau memberikan solusi dalam memecahkan masalah. (Susanti, 2014). Penelitian ini dimaksudkan untuk mengangkat fakta, keadaan, variabel, dan fenomena-fenomena yang terjadi saat sekarang (ketika penelitian berlangsung) dan menyajikannya apa adanya. Penelitian deskriptif kualitatif menuturkan dan menafsirkan data yang berkenaan dengan situasi yang terjadi sekarang. Masalah-masalah yang diamati dan diselidiki diatas memungkinkan penelitian ini memiliki metode yang mengarah pada: studi komparatif, yaitu membandingkan persamaan dan perbedaan gejala-gejala tertentu; studi kualitatif yang mengukur dan menampilkan fakta melalui teknik survei, tes, interview, dan angket; bisa pula menjadi studi korelasional satu unsur dengan unsur lainnya. Kegiatan studi deskriptif meliputi pengumpulan data, analisis data, interpretasi data, serta diakhiri dengan kesimpulan yang didasarkan pada penganalisisan data tersebut. Jadi penelitian deskriptif kualitatif adalah penelitian tentang gejala dan keadaan yang dialami sekarang oleh subjek yang sedang diteliti. Jika data yang akan diolah tinggal mengambil, memeriksa, mengumpulkan, atau paling tidak peneliti memberi tugas, memberi tes, wawancara, kemudian dikumpulkan, maka penelitian yang dilakukan adalah jenis deskriptif kualitatif.

Reduksi data meliputi berbagai kegiatan yang bertujuan untuk mempertajam analisis (Miles dan Hamberman, 1992 dalam Atmadja, 2013). Proses wawancara terhadap informan terkadang keluar dari konteks panduan wawancara yang telah disusun. Reduksi pada hasil wawancara ini dilakukan dengan menghilangkan jawaban-jawaban informan yang keluar dari konteks pertanyaan pedoman wawancara.

Maka dari itu, proses reduksi berkaitan dengan pemilahan data yang dilihat dari relevansinya dengan pertanyaan penelitian. Bahkan dalam suatu reduksi akan dibuat suatu narasi awal yang bersifat tentatif. Hal ini penting dilakukan dalam konteks pemfokusan penggalian data, yang nantinya akan mengarah pada pengujian proposisi penelitian atau menambah variasi penjelasan maupun pemaknaan yang sudah ada. Kesemuannya itu tidak dapat dilepas dari bangunan landasan teori yang sudah dibuat. Landasan teori memberikan arah tentang data apa yang dikumpulkan dan bagaimana membangunnya dalam bentuk narasi. Berkenaan dengan itu, maka triangulasi data sangat penting dilakukan dalam proses reduksi. Hal ini penting dilakukan untuk menambah validitas data lebih terjamin keabsahannya. Data yang didapat dari hasil wawancara dan observasi dapat pula ditriangulasikan dengan data dokumen, begitu sebaliknya sehingga data yang didapat lebih banyak dan keabsahannya lebih kuat.

Dalam konteks penelitian ini, analisis dilakukan dengan merujuk pada proposisi yang telah dibuat sebelumnya. Proposisi ini diuji untuk mengetahui sejauh mana dapat dipertahankan melalui bukti-bukti dalam menjawab pertanyaan penelitian. Selanjutnya hasil analisis, dimanfaatkan dalam penarikan suatu kesimpulan penelitian yang menguraikan makna subjektif, temuan konsep atas permasalahan yang diteliti. Selain itu juga, kegiatan pengumpulan data, reduksi dna penarikan kesimpulan merupakan rangkaian terkait dan bisa berlangsung secara ulang-alik, sampai mendapatkan hasil penelitian akhir yang berisfat holistic dan sarat makna dalam konteks pemberian jawaban terhadap masalah yang dikaji (Atmadja, 2006:65).

\section{Hasil dan Pembahasan \\ Peranan Value For Money}

Peranan indikator kinerja adalah untuk menyediakan informasi sebagai pertimbangan untuk pembuatan keputusan. Hal ini tidak berarti bahwa suatu indikator akan memberikan ukuran pencapaian program yang definitif. Pengembangan indikator value for money dibagi menjadi dua bagian yaitu indikator alokasi biaya (ekonomi dan efisien) dan indikator kualitas pelayanan (efektivitas).

Indikator kinerja harus dapat dimanfaatkan oleh pihak internal maupun eksternal. Pihak internal dapat menggunakannya dalam rangka meningkatkan kuantitas dan kualitas pelayanan serta efisiensi biaya. Dengan kata lain, indikator kinerja berperan untuk 
menunjukkan, memberi indikasi atau memfokuskan perhatian pada bidang yang relevan dilakukan tindakan perbaikan.

Pihak eksternal dapat menggunakan indikator kinerja sebagai kontrol dan sekaligus sebagai informasi dalam rangkaa mengukur tingkat akuntabilitas publik. Pembuatan dan penggunaan indikator kinerja tersebut membantu setiap pelaku utama dalam proses pengeluaran publik. Indikator kinerja akan membantu para manajer publik untuk memonitor pencapaian program dan mengidentifikasi masalah yang penting. Selain itu, indikator kinerja juga akan membantu pemerintah dalam proses pengambilan keputusan anggaran dan dalam mengawasi kinerja anggaran. Value for money merupakan inti pengukuran kinerja pada unit-unit kerja pemerintah. Pengembangan indikator kinerja sebaiknya memusatkan perhatian pada pertanyaan mengenai ekonomi, efisiensi, dan efektivitas program dan kegiatan.

Value for money menurut Mardiasmo (2009:4) merupakan konsep pengelolaan organisasi sektor publik yang mendasarkan pada tiga elemen utama, yaitu ekonomis, efisiensi, dan efektivitas. Ekonomi: pemerolehan input dengan kualitas dan kuantitas tertentu pada harga yang terendah. Ekonomi merupakan perbandingan input dengan input value yang dinyatakan dalam satuan moneter. Efisiensi: pencapaian otput yang maksimum dengan input tertentu untuk penggunaan input yang terendah untuk mencapai output tertentu. Efisiensi merupakan perbandingan output/input yang dikaitkan dengan standar kinerja atau target yang telah ditetapkan. Efektivitas: tingkat pencapaian hasil program dengan target yang ditetapkan. Secara sederhana efektivitas merupakan perbandingan outcome dengan output.

Menurut University of Cambridge (2010), Pendanaan Pendidikan Tinggi Dewan Inggris (HEFCE) menggambarkan nilai uang dengan cara berikut:

'Nilai untuk uang' (VFM) adalah istilah yang digunakan untuk menilai apakah organisasi telah memperoleh manfaat maksimal dari barang dan jasa yang baik memperoleh dan memberikan, dalam sumber daya yang tersedia untuk itu. Beberapa elemen mungkin subyektif, sulit diukur, tidak berwujud dan disalahpahami. Penghakiman Oleh karena itu diperlukan ketika mempertimbangkan apakah VFM telah tercapai atau tidak memuaskan. Tidak hanya mengukur biaya barang dan jasa, tetapi juga memperhitungkan campuran kualitas, biaya, penggunaan sumber daya, kesesuaian untuk tujuan, ketepatan waktu, dan kenyamanan untuk menilai apakah atau tidak, bersama-sama, mereka merupakan nilai yang baik.

\section{Simpulan}

Dari Penelitian yang dilakukan di Pemerintahan Kabupaten Buleleng yaitu kantor bupati buleleng mengenai penerapan Value For Money untuk menjalankan aktivitas operasional sehari-hari sangat berpengaruh secara signifikan antara penerapan Value For Money dengan peningkatan kinerja lembaga nonkeuangan kabupaten. Apabila pemerintah kabupaten Buleleng sudah mengoptimalkan konsep ini maka secara umum mempengaruhi kinerja lembaga nonkeuangan sendiri yang didasari oleh kepercayaaan oleh public, lembaga nonkeuangan lain dan pemerintah daerah begitu juga sebaliknya. Hal ini tentunya menjadi peranan Pimpinan dalam mengoptimalkan kinerja Organisasi sektor publik.

\section{Daftar Pustaka}

Atmadja, 2006. Bambu, Tanaman Tradisional Yang Terlupakan. http://www.freelists.org/archives/ppi/09-2006/msg00010.html

Bastian, Indra, 2006, Akuntansi Sektor Publik: Suatu Pengantar, Erlangga, Jakarta.

Bastian, Indra, 2006a, Sistem Perencanaan dan Penganggaran Pemerintahan Daerah di Indonesia, Salemba Empat, Jakarta.

Coopers PriceWaterHouse, (2006)., The World in 2050, Price Water House Coopers.

Mahsun, Mohamad, 2006. Pengukuran Kinerja Sektor Publik, Penerbit BPFE, Yogyakarta.

Mahsun, Mohamad, 2012, Pengukuran Kinerja Sektor Publik, BPFE-Yogyakarta, Yogyakarta. 
Mardiasmo, 2002, "Otonomi dan Manajemen Keuangan Daerah". Penerbit ANDI, Yogyakarta. Mardiasmo., 2009, Akuntansi Sektor Publik, Yogyakarta: ANDI

Moleong, Lexy J. (2010), Metodologi penelitian kualitatif, Remaja Rosdakarya, Bandung.

Pemerintah Republik Indonesia. Undang-Undang No. 22 Tahun 1999 Tentang Pemerintahan Daerah, Undang-Undang No. 25 Tahun 1999 Tentang

Perimbangan Keuangan Antara Pemerintah Pusat dan Daera., Bandung :Kuraiko Pratama.

Robertson, 2002, Perwujudan Akuntabilitas Instansi Pemerintah, Edisi Pertama, Pustaka Pelajar, Yogyakarta. 